\title{
PENGARUH PERCEIVED SERVICE QUALITY, PERCEIVED VALUE, SATISFACTION DAN IMAGE TERHADAP CUSTOMER LOYALTY (STUDI KASUS GARUDA INDONESIA)
}

\author{
Hartono Subagio dan Robin Saputra \\ Fakultas Ekonomi Universitas Kristen Petra Surabaya \\ Email: hartono@petra.ac.id
}

\begin{abstract}
Abstrak: PT. Garuda Indonesia merupakan sebuah perusahaan maskapai penerbangan yang menjadi salah satu pemain utama dalam industri penerbangan kelas premium di Indonesia. Penelitian perilaku konsumen tentang pengaruh perceived service quality dan perceived value terhadap loyalitas pelanggan dengan kepuasan dan image maskapai penerbangan Garuda Indonesia dengan 200 pelanggan rute Surabaya-Jakarta, dan sebaliknya. Dengan analisis kausal metode SEM mengupas pengaruh dari kualitas layanan, kenyamanan, dan catering akan membentuk corporate image (Airline Image) dan perceive value, yang kemudian mempengaruhi kepuasan dan loyalitas pelanggan Garuda Indonesia di masa mendatang. Tujuan rekomendasi penulis adalah agar PT. Garuda Indonesia dapat mengevaluasi maskapai penerbangannya, serta menjaga loyalitas pelanggannya dengan pelayanan yang berkualitas.
\end{abstract}

Kata kunci: PT. Garuda Indonesia, Pengaruh Perceived Service Quality, Perceived Value, faktor-faktor penyebab.

\begin{abstract}
PT. Garuda Indonesia constitutes an owned airline that was one of the major players in the premium class airline industry in Indonesia. The subject that the writer observes is Consumer behavior, to the influence of perceived service quality and perceived value on customer loyalty with customer satisfaction and airline image of Garuda Indonesia with 200 customer Surabaya-Jakarta route, and vice versa. Analysis SEM Certainly explain the influence of perceived service quality, convenience, and catering will form the corporate image (Airline Image) and perceived value, which in turn affects customer satisfaction and loyalty Garuda Indonesia in the future. The purpose of recommendation writer is for PT. Garuda Indonesia flight airlines to evaluate and maintain the loyalty of its customers with quality service.
\end{abstract}

Keywords: PT. Garuda Indonesia, Effect of Perceived Service Quality, Perceived Value, the factors that cause.

\section{PENDAHULUAN}

Industri jasa merupakan fenomena yang unik dalam pembangunan nasional suatu bangsa. Semakin maju suatu bangsa, maka semakin besar konstribusi komponen jasa pada struktur pendapatan nasionalnya. Industri jasa telah berkembang menjadi unsur yang penting dalam pembangunan berbagai negara di dunia. Indonesia adalah negara sedang berkembang yang mempunyai komponen industri jasa sebesar 45\% dari GNP nya negara yang lebih maju seperti Singapura mempunyai $80 \%$ dari total GNP nya dari industri jasa. Sedangkan komposisi penting industri jasa adalah transportasi dan telekomunikasi (Sukandi, 1996). Bisnis transportasi merupakan bidang yang sangat prospektif untuk masa kini dan mendatang, bisnis transportasi udara menjadi bidang yang sangat diperlukan untuk masyarakat modern dewasa ini. Salah satu keuntungannya jika dibandingkan dengan jasa transportasi yang lain adalah waktu yang singkat untuk mencapai tujuan. Konsep pemasaran, dikemukakan sebagai kunci untuk mencapai tujuan perusahaan adalah penentuan kebutuhan dan keinginan pasar sasaran serta memberikan kepuasan yang diharapkan secara lebih efisien dan efektif dibandingkan dengan para pesaing. Untuk itu ada empat pilar konsep pemasaran yaitu (a) fokus pasar, (b) orientasi kepada pelanggan, (c) pemasaran yang terkoordinasi, (d) kemampulabaan. (Kotler, 2000). Dengan berpegang dengan orientasi kepada pelanggan tujuan yang ingin dicapai adalah memuaskan pelanggan. Dilihat dari dimensi asal pelanggan yang menjadi sasaran, pelanggan dikelompokkan ke dalam dua kelompok, yaitu kelompok pembeli baru dan kelompok pembeli ulang. Dilihat dari dimensi biaya, akan lebih besar biaya untuk menarik pelanggan baru jika dibandingkan biaya untuk mempertahankan pelanggan lama atau menciptakan pembelian ulang. Oleh karena itu mempertahankan pelanggan adalah lebih penting dari pada memikat pelanggan. Adapun mempertahankan pelanggan terletak pada kepuasan pelanggan. Pada industri jasa (service), kepuasan pelanggan selalu dipengaruhi oleh Kualitas interaksi antara pelanggan dan karyawan yang melakukan kontak layanan (Kotler, 2000). Dalam dekade terakhir ini, gerakan ke arah Kualitas di seluruh dunia telah menjalar dari sektor manufaktur ke sektor jasa. Bukti dari kualitas jasa nampak pada performance yang tanpa cacat atau sempurna (Berry dan Parasuraman, 1990), suatu konsep yang sama dengan apa yang 
dinyatakan sebagai Zero defect pada manufaktur. Berdasarkan pada sudut pandang pelanggan, kontak layanan (service encounter atau dikenal dengan istilah (moment of truth) terjadi pada saat pelanggan berinteraksi dengan organisasi (perusahaan) untuk memperoleh jasa yang dibelinya. Pada dasarnya, ada dua hal pokok yang berkaitan dengan layanan, yaitu harapan pelanggan terhadap kualitas langganan (expected quality) dan persepsi pelanggan atas kualitas layanan pada saat menerima layanan (experienced atau perceive quality). Pelanggan senantiasa menilai suatu layanan yang diterima dengan membandingkannya dengan apa yang diharapkan atau yang diinginkan. Kepuasan konsumen menjadi kunci dari ukuran performance yang dikatakan sempurna, dalam hal ini tidaklah berarti memenuhi standarisasi yang kaku, tetapi performance yang dapat memberi kepuasan mendekati $100 \%$ dari sudut pandang konsumen. Pelanggan senantiasa menilai suatu layanan yang diterima dengan membandingkan dengan apa yang diharapkan atau di inginkan.

Konsumen membeli dari perusahaan yang menawarkan nilai yang tertinggi perceived value, konsumen mengevaluasi manfaat yang diterimanya dengan pengorbanan mereka untuk mendapatkan produk tersebut.

Pelanggan yang loyal adalah pelanggan yang memiliki ciri-ciri antara lain melakukan pembelian secara berulang terhadap badan usaha yang sama, memberitahukan kepada orang lain tentang kepuasankepuasan yang didapat dari perusahaan tersebut, dan menunjukkan kekebalan terhadap tawaran-tawaran dari tawaran-tawaran perusahaan pesaing lain.

Pada industri penerbangan (airline) penumpang komersial di Indonesia, perilaku konsumen dalam memilih pesawat yang ada beberapa macam, meliputi pilihan penerbangan yang memberikan harga murah, dan penerbangan yang baik dengan harga premium.

Pertimbangan Dependen maupun independen dalam keputusan pada dasarnya berbeda dengan industri lain. Rute terbang yang bisa menghubungkan dari satu kota A dengan kota lainnya B. Juga skedul keberangkatan, berapa kali frekuensi penerbangan mempengaruhi nilai dari konsumen pribadi. Seringkali keputusan konsumen juga tidak bisa sendiri karena meliputi kelompok dari travel biro, juga kesempatan penerbangan untuk keperluan bisnis atau untuk wisata. Pada rute yang hanya dilayani satu perusahaan penerbangan, akan bersifat monopoli bagi perusahaan tersebut, namun untuk rute perjalanan padat dengan banyak perusahaan memberikan skedul lebih padat dengan banyak pilihan perusahaan penerbangan.
Loyalitas pelanggan yang lebih besar, pada gilirannya, bisa ditentukan oleh kepercayaan terhadap merek maskapai dan oleh perasaan atau pengaruh yang ditimbulkan oleh merek maskapai penerbangan. Dengan tingkat penerimaan terhadap kualitas produk (perceive quality) akan memberikan rasa puas oleh karena pengharapan konsumen akan kinerja perusahaan bisa dicapai dengan baik. Kesan atau citra yang baik terhadap merek maskapai penerbangan, atas pengalaman yang didapat pelanggan akan menjadi kunci bagi maskapai penerbangan terdapat pelanggan yang loyal.

Sebagai faktor yang mempengaruhi kesan yang baik dari maskapai penerbangan adalah pengalaman yang dirasakan karena kenyamanan, kualitas layanan yang perusahaan maskapai penerbangan mampu lakukan, juga karena diberikan catering sebagai pelengkap jasa layanan penerbangan yang dilakukan. Garuda Indonesia sebagai perusahaan yang melakukan strategi harga premium dengan layanan yang prima membuat maskapai penerbangan ini mempunyai corporate image yang baik. Garuda Indonesia dikenal menggunakan strategi harga premium, memakai travel agent sebagai mitra untuk mendistribusikan tiket dengan terlebih dulu memberikan deposit sebagai perwakilan. Garuda Indonesia juga melakukan strategi tiket murah dengan adanya City Link untuk menjangkau segmen yang sensitif terhadap harga tiket yang premium.

Berdasarkan fakta-fakta di atas, penulis berkeinginan untuk meneliti dan mengidentifikasi adanya pengaruh dari kualitas layanan, kenyamanan, dan catering dalam pembentukan corporate image (Airline Image), dan perceive value yang akan mempengaruhi kepuasan dan loyalitas pelanggan Garuda Indonesia di masa mendatang.

Setelah mengetahui fakta yang spesifik dan mengidentifikasi masalah-masalah yang timbul, maka perumusan masalahnya adalah sebagai berikut.

Permasalahannya.

1. Apakah kualitas layanan yang diterima (perceived service quality) mempengaruhi kepuasan pelanggan maskapai penerbangan Garuda Indonesia?

2. Apakah kualitas layanan yang diterima (perceived service quality) mempengaruhi citra/ kesan baik (Airline Image) maskapai penerbangan Garuda Indonesia?

3. Apakah nilai yang dirasakan (perceived value) mempengaruhi kepuasan kepada maskapai penerbangan Garuda Indonesia?

4. Apakah citra/ kesan yang baik (Airline Image) mempengaruhi kepuasan pelanggan maskapai penerbangan Garuda Indonesia? 
5. Apakah citra/kesan yang baik (Airline Image) mempengaruhi loyalitas kepada maskapai penerbangan Garuda Indonesia?

Apakah kepuasan penumpang maskapai penerbangan mempengaruhi loyalitas kepada maskapai penerbangan Garuda Indonesia?

\section{TINJAUAN PUSTAKA}

\section{Pengalaman Kualitas Layanan (Perceived Service Quality)}

Kualitas pelayanan yang baik timbul karena adanya strategi pelayanan yang berkaitan dengan kebijakan-kebijakan perusahaan. Strategi pelayanan harus dapat terus dikembangkan untuk dipelihara dan ditingkatkan terutama untuk menciptakan customer loyalty. Strategi pelayanan harus dapat memberikan nilai perceive value yang diterima oleh pelanggannya, seperti pelayanan yang harus memenuhi harapan pelanggannya, maka hal ini akan memotivasi pelanggan untuk tetap setia pada perusahaan tersebut daripada harus pindah ke perusahaan pesaing.

(Parasuraman 1996)

\section{Nilai yang Dirasakan (Perceived Value)}

Nilai yang dirasakan adalah suatu bentuk yang melandasi kualitas layanan yang dirasakan, sebagai bahan nilai, kualitas layanan yang dirasakan bisa jadi dikonsepkan sebagai hasil dan pertukaran atau penjualan pelanggan antara persepsi kualitas dan pengorbanan pelanggan dalam segi keuangan maupun non keuangan. Pengorbanan non keuangan seperti waktu, fisik atau usaha psikologis .Hasil yang diperoleh dan selisih kualitas layanan dan pengorbanan yang dilakukan pelanggan akan memberikan pengaruh penilaian terhadap kepuasan pelanggan. (kotler 2006)

\section{Kepuasan Pelanggan (Customer Satisfaction)}

Kepuasan adalah tingkat perasaan seseorang setelah membandingkan kinerja atau hasil yang dirasakannya dengan harapannya. Jadi, tingkat kepuasan merupakan fungsi dari perbedaan antara kinerja yang dirasakan dengan harapan. (Kotler 2008)

\section{Citra PerusahaanCorporate Image}

Loyalitas merupakan hasil dan hubungan kepuasan akan kualitas produk yang baik. Selnes (1993) mengemukakan bahwa reputasi merek perusahaan termasuk bisa dijelaskan dan loyalitas bersama kepuasan. Andreassen dan Lindestad (1998) mengemukakan bahwa dorongan intrinsik (intrinsic cues) seperti sikap terhadap produk sangat kuat dipengaruhi produk atau jasa. sedangkan ekstrinsik cues seperti corporate image adalah hanya merupakan bagian dan produk atau jasa itu.

\section{Loyalitas Pelanggan Mendatang}

Model ini adalah menjelaskan perilaku loyalitas mendatang. Dalam bisnis travel dan tourism, loyalitas tidak dapat selalu dibuat efektif dalam pembelian tiket. Definisi loyalitas menurut Oliver (1999) adalah sebagai berikut: A deeply held commitment to rebuy or repatronize a preferred product/service consistently in the future thereby causing repetitive same brand or same brand set purchasing, despite situational influence and marketing efforts having the potential to cause switching behavior. (Chaudhuri \& Holbrook, 2001, p. 82).

Dapat dikatakan, loyalitas adalah sebuah komitmen mendalam untuk membeli kembali atau menjadi pelanggan tetap dan sebuah produk/jasa yang disukai secara konsisten dimasa yang akan datang, dimana komitmen itu menyebabkan pembelian yang berulang terhadap jasa penerbangan yang sama, bahkan mempunyai kemauan untuk merekomendasikan penyedia jasa untuk orang lain yang merupakan aspek konatif.

\section{Hipotesis Penelitian}

Berdasarkan rumusan masalah, tinjauan pustaka, maka dapat disusun hipotesis penelitian sebagai berikut:

1. Kualitas layanan (perceived service quality) mempunyai pengaruh terhadap kepuasan pelanggan maskapai penerbangan Garuda Indonesia.

2. Kualitas layanan (perceived service quality) mempunyai pengaruh terhadap kesan baik/citra (airline image) maskapai penerbangan Garuda Indonesia.

3. Nilai yang dirasakan (perceived value) mempunyai pengaruh terhadap kepuasan pelanggan maskapai penerbangan Garuda Indonesia.

4. Kesan baik/Citra (Airline Image) maskapai penerbangan mempunyai pengaruh terhadap kepuasan pelanggan maskapai penerbangan Garuda Indonesia.

5. Kesan baik/Citra (Airline image) maskapai penerbangan mempunyai pengaruh terhadap loyalitas pelanggan maskapai penerbangan Garuda Indonesia.

6. Kepuasan pelanggan mempunyai pengaruh terhadap loyalitas pelanggan maskapai penerbangan Garuda Indonesia. 


\section{METODE PENELITIAN}

\section{Jenis Penelitian}

Jenis penelitian dari kausal konklusif, yaitu penelitian yang bertujuan untuk memperoleh suatu kesimpulan dari data-data yang telah diperoleh dan diolah menjelaskan hubungan-hubungan sebab akibat antara variabel-variabel yang dibahas dalam penelitian ini.

\section{Gambaran Populasi dan Sampel}

Yang menjadi target populasi dan penelitian ini adalah penumpang yang menggunakan layanan jasa penerbangan rute domestik Garuda Indonesia tiga bulan, jumlah populasi tidak diketahui infinitif sehingga sampel yang diambil bersifat non probabilistik. Tehnik pengambilan sampel adalah Judment sampling

Sampel yang diambil 200 orang responden yang terdiri atas penumpang maskapai Garuda Yang baru turun dari pesawat.

\section{Prosedur Pengumpulan Data}

Data penelitian diperoleh dengan menggunakan kuesioner, yaitu melalui daftar pertanyaan yang disusun secara sistimatis dengan beberapa pilihan jawaban yang mudah dipahami dengan menggunakan skala likert.

\section{Klasifikasi Variabel}

Adapun yang menjadi variabel bebas adalah kualitas layanan diterima (perceived service quality) sedangkan variabel antara adalah nilai yang dirasakan (perceived value), Citra maskapai penerbangan (Airline Image) dan kepuasan pelanggan (customer satisfaction) dan variabel tak bebas adalah loyalitas pelanggan.

\section{Teknik Analisis Data}

Untuk menjawab rumusan masalah dan melakukan pengujian terhadap hipotesis yang diajukan, maka data yang diperoleh selanjutnya akan diolah sesuai dengan kebutuhan analisis. Untuk kepentingan pembahasan, data diolah dan dipaparkan berdasarkan prinsip-prinsip statistik deskriptif, Sedangkan untuk kepentingan analisis dan pengujian hipotesis digunakan metode Structural Equation Modeling (SEM).

\section{Analisis SEM}

Penelitian ini bertujuan menguji dan menganalisis hubungan kausal antara variabel independen dan dependen, sekaligus memeriksa validitas dan reliabilitas instrumen penelitian secara keseluruhan. Oleh karena itu digunakan tehnik analisis Structural Equation Modeling (SEM) dengan menggunakan paket program AMOS (Analysis of Moment Structure) versi 4.0. SEM merupakan sekumpulan tehniktehnik yang memungkinkan pengujian beberapa variabel dependen dengan beberapa variabel independen secara simultan Ghozali (2003) mengungkapkan bahwa SEM memungkinkan untuk dapat menjawab pertanyaan penelitian yang bersifat represif maupun dimensional yaitu mengukur dimensi dari sebuah konsep atau konstruk dan pada saaat yang sama ingin mengukur pengaruh atau derajat hubungan antar faktor yang telah diidentifikasikan dimensidimensinya, maka SEM akan memungkinkan untuk melaksanakannya. SEM juga merupakan pendekatan terintegrasi antara analisis faktor da, model struktural dan analisis jalur.

Penggunaan SEM memungkinkan untuk menguji hubungan antar variabel yang kompleks, untuk memperolaeh gambaran menyeluruh mengenai keseluruhan model. SEM juga dapat menguji secara bersama-sama (Ghozali 2003):

1. Model struktural hubungan antara konstruk independen dan dependen.

2. Model measurement hubungan (nilai Loading) antara indikator dengan konstruk

\section{PEMBAHASAN}

\section{Uji validitas dan Reliabilitas (Convergent Validity dan Reliability Construct )}

Berikut adalah hasil pengujian validitas konvergen dan reliability construct untuk masing-masing indikator pada tiap variabel penelitian.

Tabel 1. Hasil Uji Convergent Validity dan Reliability Construct Variabel Perceived service quality

\begin{tabular}{ccccc}
\hline \multirow{2}{*}{ Dimensi } & \multicolumn{3}{c}{ Uji Validitas } & Contruct \\
\cline { 2 - 4 } & Estimate & Keterangan & GFI & Reliability \\
\hline $\mathrm{T}$ & 0.838 & Valid & 0.990 & 0.889 \\
$\mathrm{R}$ & 0.710 & Valid & Valid & Reliabel \\
$\mathrm{RS}$ & 0.778 & Valid & Unidimen- & \\
$\mathrm{A}$ & 0.839 & Valid & sionalitas & \\
$\mathrm{E}$ & 0.751 & Valid & & \\
\hline
\end{tabular}


Berdasarkan tabel 1, diketahui bahwa semua item pertanyaan pada variabel perceived service quality mempunyai nilai standardized regression weight lebih besar dari 0.5 , nilai GFI mendekati 1 serta nilai construct reliability sebesar 0.889 . Dengan demikian item-item pertanyaan yang membentuk variabel perceived service quality adalah valid dan reliabel.

Tabel 2. Hasil Uji Convergent Validity dan Reliability Construct Variabel Perceived Value

\begin{tabular}{ccccc}
\hline \multirow{2}{*}{ Dimensi } & \multicolumn{3}{c}{ Uji Validitas } & Contruct \\
\cline { 2 - 4 } & Estimate & Keterangan & GFI & Reliability \\
\hline PV1 & 0.574 & Valid & 1.000 & 0.613 \\
PV2 & 0.527 & Valid & Valid Unidi- & Reliabel \\
PV3 & 0.660 & Valid & mensionalitas & \\
\hline
\end{tabular}

Berdasarkan tabel 2, diketahui bahwa semua item pertanyaan pada variabel perceived value mempunyai nilai standardized regression weight lebih besar dari 0.5 , nilai GFI sebesar 1 serta nilai construct reliability sebesar 0.613. Dengan demikian item-item pertanyaan yang membentuk variabel perceived value adalah valid dan reliabel.

Tabel.3. Hasil Uji Convergent Validity dan Reliability Construct Variabel Image

\begin{tabular}{ccccc}
\hline \multirow{2}{*}{ Dimensi } & \multicolumn{3}{c}{ Uji Validitas } & Contruct \\
\cline { 2 - 4 } & Estimate & Keterangan & GFI & Reliability \\
\hline I1 & 0.690 & Valid & 1.000 & 0.669 \\
I2 & & Valid & Valid & Reliabel \\
& 0.727 & & $\begin{array}{c}\text { Unidimen- } \\
\text { sionalitas }\end{array}$ \\
\hline
\end{tabular}

Berdasarkan tabel 3, diketahui bahwa semua item pertanyaan pada variabel image mempunyai nilai standardized regression weight lebih besar dari 0.5 , nilai GFI sebesar 1 serta nilai construct reliability sebesar 0.669. Dengan demikian item-item pertanyaan yang membentuk variabel image adalah valid dan reliabel.

Tabel 4. Hasil Uji Convergent Validity dan Reliability Construct Variabel Customer Satisfaction

\begin{tabular}{ccccc}
\hline \multirow{2}{*}{ Dimensi } & \multicolumn{3}{c}{ Uji Validitas } & Contruct \\
\cline { 2 - 4 } & Estimate & Keterangan & GFI & Reliability \\
\hline C1 & 0.768 & Valid & 1.000 & 0.721 \\
C2 & 0.551 & Valid & Valid & Reliabel \\
C3 & 0.714 & Valid & $\begin{array}{c}\text { Unidimen- } \\
\text { sionalitas }\end{array}$ \\
\hline
\end{tabular}

Berdasarkan tabel 4, diketahui bahwa semua item pertanyaan pada variabel customer satisfaction mempunyai nilai standardized regression weight lebih besar dari 0.5, nilai GFI sebesar 1 serta nilai construct reliability sebesar 0.721 . Dengan demikian item-item pertanyaan yang membentuk variabel customer satisfaction adalah valid dan reliabell

Tabel 5. Hasil Uji Convergent Validity dan Reliability Construct Variabel Customer Loyalty

\begin{tabular}{ccccc}
\hline \multirow{2}{*}{ Dimensi } & \multicolumn{3}{c}{ Uji Validitas } & Contruct \\
\cline { 2 - 4 } & Estimate & Keterangan & GFI & Reliability \\
\hline L1 & 0.758 & Valid & 1.000 & 0.728 \\
L2 & & Valid & Valid & Reliabel \\
& 0.755 & & Unidimen- & \\
& & & sionalitas \\
\hline
\end{tabular}

Berdasarkan tabel 5, diketahui bahwa semua item pertanyaan pada variabel customer loyalty mempunyai nilai standardized regression weight lebih besar dari 0.5 , nilai GFI sebesar 1 serta nilai construct reliability sebesar 0.728 . Dengan demikian item-item pertanyaan yang membentuk variabel customer loyalty adalah valid dan reliabel.

\section{Analisis Structural Equation Modelling (SEM)}

Setelah dilakukan percobaan modifikasi model berdasarkan indeks modifikasi, model menghasilkan evaluasi yang relatif lebih baik dari sebelumnya.

Tabel 6. Pengujian Goodness of Fit Model Struktural Modifikasi

\begin{tabular}{lccl}
\hline \multicolumn{1}{c}{ Good of fit index } & $\begin{array}{c}\text { Cut-off } \\
\text { value }\end{array}$ & $\begin{array}{c}\text { Hasil } \\
\text { model }\end{array}$ & Keterangan \\
\hline Chi-Square $(\mathrm{df}=50)$ & $\leq 67.505$ & 65.884 & Baik \\
Probability Chi-Square & $\geq 0.05$ & 0.066 & Baik \\
Cmin/DF & $\leq 2.00$ & 1.317 & Baik \\
RMSEA & $\leq 0.08$ & 0.040 & Baik \\
GFI & $\geq 0.90$ & 0.960 & Baik \\
AGFI & $\geq 0.90$ & 0.904 & Baik \\
\hline
\end{tabular}

Berdasarkan tabel 6, terlihat bahwa hasil evaluasi model yang lebih baik dari hasil goodness of fit pada tahap awal. Dengan demikian untuk melakukan pengujian hipotesis penelitian, digunakan model setelah dilakukan modifikasi.

Berikut adalah Regression Weight dan Standardized Regression Weight model persamaan struktural yang telah dimodifikasi seperti pada tabel 7 . 
Tabel 7. Regression Weight dan Standardized Regression Weight Structural Model Struktural Modifikasi

\begin{tabular}{lccccc}
\hline \multicolumn{2}{c}{ Standardized Estimate } & & SE & C.R. & P \\
\hline Image & $\begin{array}{l}\text { Service_ } \\
\text { Quality }\end{array}$ & 0.693 & 0.101 & 11.490 & 0.000 \\
$\begin{array}{l}\text { Customer_ } \\
\text { Service_ } \\
\text { Quality }\end{array}$ & 0.512 & 0.229 & 2.852 & 0.004 \\
$\begin{array}{l}\text { Satisfaction } \\
\text { Customer_ }\end{array}$ & $\leftarrow$ Perceived_ & 1.189 & 0.335 & 4.826 & 0.000 \\
$\begin{array}{l}\text { Satisfaction } \\
\text { Value }\end{array}$ & & & & \\
$\begin{array}{l}\text { Customer_ } \\
\text { Satisfaction }\end{array}$ & $\leftarrow$ Image & 0.490 & 0.177 & 2.113 & 0.035 \\
$\begin{array}{l}\text { Loyalty } \\
\text { Loyalty }\end{array}$ & $\leftarrow$ Image & 0.211 & 0.088 & 2.118 & 0.034 \\
& Customer_ & 0.859 & 0.112 & 8.868 & 0.000 \\
\hline
\end{tabular}

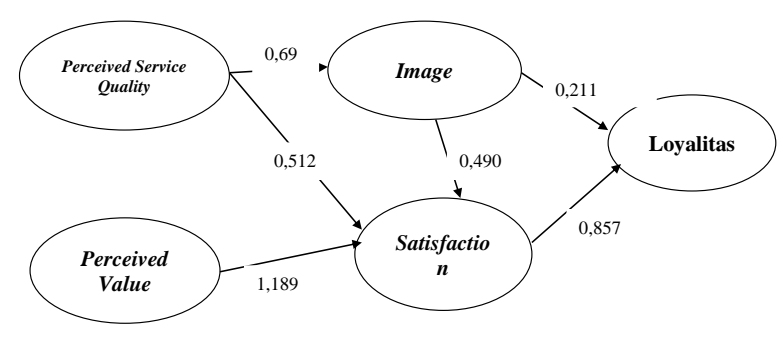

Gambar 1 Model Hubungan struktural

Persamaan matematis yang menyatakan hubungan sebab akibat tersebut dapat dilihat loyalitas dipengaruhi kepuasan dan citra.

Image $=+0,69$ Perceived service quality (1)

Kepuasan $=+0,490$ image $+0,512$ perceive service quality+ 1.189 Perceived value (2).

Loyalitas $=+0,211$ image $+0,857$ satistafation (3)

Untuk menemukan persamaan model struktural penelitian ini, digunakan paket program statistik Amos. Hasil olahan menampilkan bentuk diagram yang menunjukkan koefisien dugaan parameter regresi yang menunjukkan pengaruh secara statistik. Berdasarkan hasil Regresi dengan analisis jalur diperoleh nilai koefisien regreasi perceived service quality terhadap image adalah 0,69. Dengan demikian hipotesis yang menduga bahwa perceived service quality berpengaruh signifikan terhadap image terbukti kebenarannya. Hasil ini menunjukkan bahwa kualitas layanan yang diterima (perceive quality) mempengaruhi citra/kesan baik (Airline Image) maskapai penerbangan Garuda Indonesia.

Berdasarkan hasil analisis diperoleh nilai koefisien regreasi perceived service quality terhadap customer satisfaction adalah 0,512. Dengan demikian hipotesis yang menduga bahwa perceived service quality berpengaruh signifikan terhadap customer satisfaction terbukti kebenarannya. Hasil ini menunjukkan bahwa kualitas layanan yang diterima (perceive quality) mempengaruhi kepuasan pelanggan maskapai penerbangan Garuda Indonesia.
Berdasarkan hasil analisis diperoleh nilai regresi image terhadap customer satisfaction adalah 0,490. Dengan demikian hipotesis yang menduga bahwa image berpengaruh signifikan terhadap customer satisfaction terbukti kebenarannya. Hasil ini menunjukkan bahwa citra/ kesan yang baik (Airline Image) mempengaruhi kepuasan pelanggan maskapai penerbangan Garuda Indonesia.

Berdasarkan hasil analisis diperoleh nilai koefisien regresi image terhadap customer loyalty adalah 0,211 . Dengan demikian hipotesis yang menduga bahwa image berpengaruh terhadap customer loyalty terbukti kebenarannya. Hasil ini menunjukkan bahwa citra/ kesan yang baik (Airline Image) mempengaruhi loyalitas kepada maskapai penerbangan Garuda Indonesia.

Berdasarkan hasil analisis diperoleh nilai regresi customer satisfaction terhadap customer loyalty adalah 0,857 . Dengan demikian hipotesis yang menduga bahwa customer satisfaction berpengaruh signifikan terhadap customer loyalty terbukti kebenarannya. Hasil ini menunjukkan bahwa kepuasan penumpang maskapai penerbangan mempengaruhi loyalitas kepada maskapai penerbangan Garuda Indonesia.

\section{Hasil Temuan}

Perceived Service Quality Terhadap Customer Satisfaction; Airline Image

Hasil analisis tersebut menunjukkan bahwa apabila kualitas layanan yang diterima tinggi maka hal itu akan menghasilkan kepuasan dan citra yang tinggi di mata pelanggan. Perusahaan Garuda Indonesia melalui kinerja seluruh karyawan membentuk citra maskapai penerbangan sehingga pelanggan dapat menilai melalui kualitas layanan. Semakin baik kualitas layanan, maka semakin besar kemungkinan pelanggan untuk puas dan semakin besar pula kemungkinan citra perusahaan baik di mata konsumen.

Kepuasan pelanggan dan citra perusahan berawal dari komitmen perusahaan memperlakukan konsumennya secara baik. Dan perlu diingat bahwa Image atau citra dibentuk dalam benak konsumen melalui konsumen (iklan, public relations, citra fisik, word of mouth communication) yang dikombinasikan dengan pengalaman sendiri konsumen itu sendiri. Apabila hal ini diteruskan, tentunya akan berdampak kepada loyalitas pelanggan. Ini membuktikan bahwa kualitas layanan dan citra perusahaan merupakan faktor pembentuk kepuasan yang penting bagi industri jasa penerbangan. 


\section{Perceived Value Terhadap Customer Satisfaction}

Hasil penelitian menunjukkan bahwa perceived value berpengaruh terhadap kepuasan konsumen pada maskapai penerbangan Garuda Indonesia. Hasil ini menunjukkan bahwa responden menilai sejauh mana perceived value ikut menentukan sejauh mana tingkat kepuasan konsumen. Semakin baik perceived value, maka semakin besar kemungkinan pelanggan untuk puas. Kepuasan merupakan ukuran sebenarnya tentang bagaimana penerimaan dan kesesuain konsumen terhadap suatu merek, dan kepuasan adalah ukuran sebenarnya untuk bisnis jasa. Kepuasan pelanggan berawal dari komitmen perusahaan memperlakukan konsumennya secara baik. Ini membuktikan bahwa perceived value merupakan elemen yang penting dalam pembentukan kepuasan khususnya dalam usaha jasa.

Perceived value yang meningkat akan menghasilkan konsumen yang puas. Hubungan konsumen dengan perusahaan diperkuat ketika konsumen mendapatkan hasil yang memadai tentang perceived value perusahaan dan menjadi lemah ketika konsumen mendapatkan hasil negatif tentang perceived value perusahaan.

\section{$\underline{\text { Image Terhadap Customer Satisfaction; Loyalty }}$}

Hasil penelitian menunjukkan bahwa citra (airline image) berpengaruh terhadap satisfaction / kepuasan dan loyality/loyalitas konsumen pada Garuda Indonesia. Hasil ini menunjukkan bahwa citra perusahaan yang timbul di benak konsumen ikut menentukan sejauh mana kepuasan dan loyalitas konsumen. Airline image menimbulkan ekspektasi dan harapan tersendiri dari konsumen terhadap maskapai penerbangan Garuda Indonesia. Ekspektasi dan harapan yang keluar dari benak konsumen ini tentunya diupayakan dapat terjawab oleh perusahaan penyedia jasa dengan baik, karena hal ini yang menciptakan citra baik perusahaan dan berujung kepada kepuasan dan loyalitas konsumen. Apabila citra perusahaan sudah baik di mata konsumen, maka tingkat kepercayaan konsumen semakin tinggi kepada perusahaan penyedia jasa, dan berani mengambil keputusan pembelian dan juga mereferensikan ke orang lain. Citra perusahaan yang baik, juga terakumulasi dari perasaan emosional konsumen atas dasar pertimbangan pengalaman positif mereka, yang dihasilkan oleh proses komunikasi langsung, maupun tidak langsung. Jadi perlu diperhatikan bahwa reputasi / image / citra perusahaan akan membentuk kepuasan atas jasa yang dikonsumsi dan menghasilkan loyalitas konsumen.

\section{Customer Satisfaction Terhadap Loyalty}

Hasil penelitian menunjukkan bahwa kepuasan (satisfaction) berpengaruh terhadap loyalitas konsumen pada Garuda Indonesia. Hasil ini menunjukkan bahwa kepuasan yang dirasakan pelanggan sudah tentu loyal terhadap maskapai penerbangan Garuda Indonesia karena persaingan yang semakin ketat diantara penyedia jasa penerbangan menyebabkan konsumen mempunyai banyak pilihan dalam memilih penyedia jasa tersebut, dimana konsumen lebih memperhatikan kepuasan.

Kepuasan (Satisfaction) menggambarkan tanggapan sesudah pembelian dari seorang konsumen terhadap sebuah produk/jasa yang diyakini tepat atau ada kecocokan antara apa yang diharapkan oleh pelanggan dengan kinerja jasa yang telah diterimanya. Kepuasan konsumen terhadap produk/jasa tidak hanya ditentukan dari kecocokan antara harapan dengan kinerja produk/jasa tersebut, tetapi juga ditentukan oleh kualitas pelayanan dari penyedia jasa.

\section{KESIMPULAN DAN SARAN}

\section{Kesimpulan}

Pengujian hipotesis penelitian yang dilakukan dengan mempergunakan analisis diperoleh sebagai berikut:

1. Hasil analisis regresi menunjukan perceived service quality berpengaruh terhadap terhadap image. Dengan demikian hipotesis yang menduga bahwa service quality berpengaruh signifikan terhadap image terbukti.

2. Berdasarkan hasil analisis regresi perceived service quality berpengaruh terhadap customer satisfaction. Dengan demikian hipotesis yang menduga bahwa service quality berpengaruh signifikan terhadap customer satisfaction terbukti kebenarannya. Maka, kualitas layanan secara positif mempengaruhi kepuasan pelanggan PT. Garuda Indonesia. Dengan demikian H2 diterima.

3. Berdasarkan hasil analisis regresi perceived value berpengaruh terhadap customer satisfaction. Dengan demikian hipotesis yang menduga bahwa perceived value berpengaruh signifikan terhadap customer satisfaction terbukti kebenarannya. Maka, nilai yang dirasakan secara positif mempengaruhi kepuasan pelanggan. Dengan demikian $\mathrm{H} 3$ diterima.

4. Berdasarkan hasi analisis regresi image berpengaruh terhadap customer satisfaction. Dengan demikian hipotesis yang menduga bahwa image berpengaruh signifikan terhadap customer satis- 
faction terbukti kebenarannya. Maka, image secara positif mempengaruhi kepuasan pelanggan PT. Garuda Indonesia. Dengan demikian H4 diterima.

5. Berdasarkan hasil analisis regresi image berpengaruh terhadap customer loyalty. Dengan demikian hipotesis yang menduga bahwa image berpengaruh signifikan terhadap customer loyalty terbukti kebenarannya. Maka, image secara positif mempengaruhi customer loyalty. Dengan demikian $\mathrm{H} 5$ diterima.

6. Berdasarkan hasil analisis regresi diperoleh customer satisfaction berpengaruh terhadap customer loyalty. Dengan demikian hipotesis yang menduga bahwa customer satisfaction berpengaruh signifikan terhadap customer loyalty terbukti kebenarannya. Maka, customer satisfaction secara positif mempengaruhi customer loyalty. Dengan demikian H6 diterima.

\section{Saran}

Dari hasil penelitian ada beberapa yang disampaikan sebagai saran sebagai berikut:

1. Ketidakpuasan konsumen dalam masalah harga sebaiknya perlu diperhatikan perusahaan. Dengan persaingan bisnis sekarang, banyak maskapai penerbangan yang menawarkan rute penerbangan domestik, internasional yang hampir sama dengan Garuda Indonesia, tetapi dengan harga yang lebih murah. Sebaiknya Garuda Indonesia bukan menurukan harganya, tapi mengkomunikasikan kepada konsumen bahwa layanan yang diberikan sesuai dengan harga yang ditawarkan. Yaitu dengan memperkuat Image perusahaan bahwa Garuda Indonesia memberikan layanan premium dan lengkap kepada konsumen, dengan tidak memangkas biaya-biaya operational seperti makanan, snack, dll. Dan pihak Garuda Indonesia juga dapat mengarahkan konsumen yang sensitif harga ini kepada anak perusahaannya, yaitu Citylink, dimana harga yang ditetapkan lebih murah ketimbang harga jasa penerbangan Garuda Indonesia.

2. Untuk meningkatkan kualitas layanan perusahaan sebaiknya memperhatikan ketepatan waktu (punctuality), dengan melakukan evaluasi, dan perbaikan kinerja dalam jadwal keberangkatan penerbangan agar mengurangi terjadinya delay keberangkatan pesawat, karena maskapai penerbangan Garuda Indonesia melayani para pebisnis yang memperhatikan OTP (On Time Performance) dan tidak mau dirugikan karena jadwal yang berubah-ubah. Serta dalam penanganan bagasi baik luggage checking, maintaining dan pengembalian bagasi dalam kondisi utuh.

3. Untuk meningkatkan loyalitas pelanggan, perusahaan sebaiknya lebih memperhatikan inflight service/pelayanan di udara, dimulai dari kinerja seluruh awak kabinnya, dengan cara selalu mengontrol awak kabin dalam bekerja sehingga dalam melayani konsumen dapat lebih mengarahkan, bersikap ramah dan sopan selalu dan tentunya dapat mengoperasikan fasilitas yang ada di kabin pesawat, seperti inflight entertainment, tempat duduk, dll.

4. Untuk meningkatkan kepuasan pelanggan, perusahaan dapat terus berinovasi dalam pelayanan, dan memberikan garansi atau jaminan pelayanan perusahaan yang lebih baik lagi. Perusahaan juga sebaiknya memperhatikan kesetiaan pelanggan agar tetap terjaga dan juga tanpa mengesampingkan faktor-faktor lain, seperti masalah Kenyamanan, reservasi dan ticketing, ketersediaan penerbangan, layanan chek in.

5. Untuk meningkatkan loyalitas pelanggan, perusahaan dapat memperkuat strategi CRM (Customer Relationship Management) seperti GFF (Garuda Frequent Flyer), dan memberikan fasilitas yang lebih dan berbeda daripada sebelumnya. Jika sebelumnya diberikan fasilitas free ticket (sesuai dengan millage yang diakumulasikan), extra baggage allowance (20kg menjadi $25 \mathrm{~kg}$ ), line antri khusus, dll. Maka loyalitas pelanggan dapat ditingkatkan dengan dengan cara membuka jalur point redemption yang baru, jadi tidak hanya terpatok pada poin pembelian tiket penerbangan saja, tapi juga bisa diperluas dengan menggunakan partner-partner lain seperti hotel chain tertentu, dan restaurant chain tertentu.

\section{DAFTAR PUSTAKA}

Aaker, David A. (1991). Managing Brand Equity: Capitalizing on the Value of Brand Name, Prentice Hall, New York.

Assael, H. (1998). Consumer Behavior and Marketing Action $\left(2^{\text {nd }}\right.$ ed) USA: PWS KENT.

Andreasen, JW, and Lindestad. (1998). Customer Loyalty and Complex Services: International. Journal of Service Industry Management vol. 9.

Bhagyalakshmi Vankatesh' ET Nargundkar. (2006). Service Quality Perceptions of Domestic Airline Consumers in India; An Empirical Study. Journal of Management Pesit, $100 \mathrm{ft}$ Ring Road, Bangalore.

Berry L.L., VA Zeithaml, \& A Parasuraman. (1990). Five Imperatives for Improving Service Quality, Sloan Management Review, Summer 29-38. 
Brown SP, RA Peterson. (1993). Antecedents and Consequences of Salesperson Job Satisfaction: Meta Analysis and Assessment of Causal Effects. Journal of Marketing Research, 30: 6377.

Brown TJ, GA Churchill, Jr, \& JP Peter. (1993). Improving the Measurement of Service Quality. Journal of Retailing, 69: 127-139.

Cardozo R. (1964). Customer Satisfaction: Laboratory Study and Marketing Action. Journal of Marketing Research, 2: 244-249.

Chaudhuri; Morris B Holbrook The Chain of Effects from Brand Trust and Brand Affect to Brand Performance, Journal of Marketing; Apr 2001; 65,2 ;

Churshill GA, C Suprenant. 1982. An Investigation into the determinants of Customer Satisfaction, Journal of Marketing Research, 19: 491-504.

Cooper, D.R \& Emory, W. (1996). Business Research Method. University of California.

Day RL, HK Hut. (1979). New Dimension of Consumer Satisfaction and Complaining Behavior. Bloomington, IN: Indiana University Press.

Dick, AS and Basu K. (1994). Customer Loyalty to ward and integrated Conceptual Frame Work: Journal of the Academy of Marketing Science vol. 22.

Engel JF, RD Blackwell \& Miniard, PW. (1995). Consumer Behavior. $7^{\text {th }}$ ed. Orlando The Dryden Press.

Fisk RP, CE Young. Disconfirmation of Equity Expectations: Effects on Consumer Satisfaction with Services, In Advances in Consumer Research. Provo, UT; Association for Consumer Research.

Fornell LA. (1992). A National Customer Satisfaction Barometer the Swedish Experience. Journal Marketing, Vol. 56.

Ghozali, Imam.2005 Aplikasi Analysis Multivariate Dengan Program SPSS, Semarang: Badan penerbit Universitas Diponegoro..

-------, Imam (2006), Structural Equation Modeling Metode Alternatif dengan Partial Least Square, Badan Penerbit Universitas Diponegoro, Semarang.

------, (2008), Model Persamaan Struktural Konsep dan Aplikasi dengan Program Amos 16.0, Badan Penerbit Universitas Diponegoro, Semarang.

Gronroos C. (1990). Service Management and Marketing. Lexington, MA; Lexington Books.

Groonroos C. (1993). Strategic Management and Marketing In the Service Sector, Marketing Science Institute Working Paper Series, report No. 83-104 Cambridge, MA Marketing Science Institute.
Halstead D., D Hartmant, SL Schmidt. (1994). Multisources Effects on Satisfaction Formation Process. Journal of the Academy of Marketing Science, 22: 114-129.

Hartono, Subagio (2003) naskah ujian kualifikasi pengaruh perceive sevice quality, perceive value, image dan satisfaction terhadap loyalitas konsumen Garuda.

Jin Wo Park, Rodger Robertson, \& Cheng Lung Wu. (2003). The Effects of Individual Dimension of Service Quality, Findings From Australian Domestic Air Passengers. Journal of Service Marketing vol. 15.

Kartajaya H. (1994). The Strategic Marketing Plus 2000; Conceptual Framework for Competitive Audit, Strategy Formulation and Capability Enhancement Swasembada, Agustus 1994.

Kotabe, Masaaki \& Hetzen, Kristian. (2010). Global Marketing Management, $5^{\text {th }}$ edition John Willey $\&$ Sons inc. New York.

Kotler P (2000) Marketing Management: Analysis, Planning, Implementation and Control. Milenium edition Englewoods Cliffs, NJ: PrenticeHall International.

Kotler P. \& Garry Amstrong. (2008). Principles of Marketing $12^{\text {th }}$ edition Prentice Hall International by Pearson Education.

LaTour SA, NC Peat. (1979). Conceptual and Methodological Issues in Consumer Satisfaction Research. In Advances in Consumer Research. Ann Arbor, MI; Association for Consumer Research, 431-437.

LaTour SA. (1980). The Role of Situationally- Produced Expectations, others Experiences, and Prior Experience in Determining Consumer Satisfaction, in Advance in Consumer Research. Ann Arbor, MI; Association for Consumer Research; 588-592.

Lovelock, Christopher H. (2010). Services Marketing $6^{\text {th }}$ edition Prentice-Hall International.

Miller JA. (1997). Studying Satisfaction, Modifying Models, Eliciting Expectations, Posing Problems and Making Meaningful Measurements in Conceptualization and Measurement of Consumer Satisfaction and Disatisfaction. H. Keith Hunt, ed. Cambridge, MA: Marketing Science Institute; 17-91.

Morris EW. (1977). A Normative Defisit Approach to Consumer Satisfaction, in Conceptualization and Measurement of Consumer Satisfaction and Dissatisfaction, HK Hunt, ed Cambridge, MA; Marketing Science Institute, 240-274.

Mowen JC \& Michael Minor (2001). Consumer Behavior: a framework, International edition New Jersey Prentice-Hall International Inc. 
Moorman, C. Deshpande \& Zaltman G. (1993). Factor's Affecting Trust in Market Relationship Journal Marketing vol. 59.

Nasution DS. (1995). Pengukuran Tingkat Kepuasan Pelanggan, Studi Kasus di PT Merpati Nusantara. Tugas Sarjana, Institut Teknologi Bandung, Bandung.

Olhavsky R, JA Miller. (1972). Consumer Expectations, Product Performance and Perceived Product Quality. Journal of Marketing Research, 17: 46-49.

Oliver RL. (1980). A Cognitive Model of the Antecedents and Consequences of Satisfaction Decision. Journal of Marketing Research, 17, 46-49.

Ostrowski. Peter L, Terence V O'Brien, and Geoffrey L. Gordon. (1993). Service Quality and Customer Loyalty in the Commercial Airline Industry, Journal of Travel Research, 16.

Oliver RL (1993). Cognitive, Affective, and Attribute Bases of the Satisfaction Response. Journal of Consumer Research, 20: 418-430.

Parasuraman A, VA Zeithaml, \& LL Berry. (1996). A Conceptual Model of Service Quality and Its Implications for Future Research. Journal of Marketing, 49; 41-50.

Parasuraman A, (1988). SERVQUAL; A Multi Item Scale for Measuring Consumer Perception of Service Quality. Journal of Retailing, 64; 12-40.

Pepers. Don \& Rogers, Martha. (2006). Managing Customer Relationships, Strategic Frame Work. John Willy \& Sons Inc., Hobokan New Jersey.

Pritchard, MP and Howard DR. (1999). The Loyal Traveler Examininga Tipology of Service Patronage Journal of Travel Research, vol. 35, 2-10.

Schiffman LG, LL Kanuk. (1997). Consumer Behavior $6^{\text {th }}$ editions. Upper Saddle River, New Jersey, Prentice-Hall, Inc.
Schumacker, R.E \& Lomax, R.G. (2004). A beginner's guide to structural equation modeling. The inquiry and pedagogy across diverse context series.

Shaw S. (2007). Airline Marketing $\&$ Management $6^{\text {th }}$ edition. Malabar, FL; Krieger Publishing Company.

Selnes F (1993)An examination of the effect of product performance on brand reputation, satisfaction and loyalty. European Journal of Marketing, 27 februari 1993

Solimun (2002). Multivariate Analysis Structural Equation Modeling (SEM). Penerbit Universitas Negeri Malang: Malang.

Solomon, MR., Marshall GW., \& Stuart, EW. (2003). Marketing Real People Real Choices $7^{\text {th }}$ edition New Jersey Prentice Hall International Inc.

Tor Wallin Andreassen, Bodil Lindestad. (1998). The Effect of Corporate Image in the Formation of Customer Loyalty, Journal of Service Research 1: 82-92.

Wikipedia ensiklopedia bebas. (2011). Daftar maskapai penerbangan Indonesia. Retrieved March 09, 2011, from http://id.wikipedia.org/wiki/ Daftar_maskapai_penerbangan_Indonesia

Zeithaml VA, Bitner MJ. (2003). Services Marketing $3^{\text {rd }}$ edition New York The McGraw Hill Company, Inc.

Zeithaml VA, Bitner MJ \& Gremler, Dwaine D. (2006). Services Marketing (Integrating Customer Focus Across the Firm) $4^{\text {th }}$ edition McGraw Hill Irwin, New York.

Zins. Anderas H. (2001). Relative Attitudes and Commitment in Customer Loyalty Models. Some experiences in the commercial airline industry, International Journal of Service Industry Management vol. 12; 3. 